\title{
The Effect of Atmosphere on Elemental Mercury Release During Thermal Treatment of Two Bituminous Coals
}

\author{
Libing Gao, Shaoqing Guo, * Xian-Xian Wei and Yanzhi Cao \\ School of Environment and Safety, Taiyuan University of Science and Technology, 030024 Shanxi, \\ Taiyuan, China
}

\begin{abstract}
The dynamic release behavior of elemental $\mathrm{Hg}\left(\mathrm{Hg}^{0}\right)$ during thermal treatment of two bituminous coals was studied under $\mathrm{N}_{2}, \mathrm{CO}_{2}$ and air atmospheres. The results show that the profiles of $\mathrm{Hg}^{0}$ released present several peaks during thermal treatment of two bituminous coals. The $\mathrm{Hg}$ peak profiles for the same coal are different with the different atmosphere used. The amount of $\mathrm{Hg}^{0}$ released from the coals is about 92-94, 73-74 and 31-33\% under $\mathrm{N}_{2}, \mathrm{CO}_{2}$ and air atmosphere, respectively. This indicates that the $\mathrm{Hg}^{0}$ is the dominant form during thermal treatment of the coals under $\mathrm{N}_{2}$ atmosphere whereas part of $\mathrm{Hg}^{0}$ is converted into the oxidized $\mathrm{Hg}$ during thermal treatment of the coals under $\mathrm{CO}_{2}$ and air atmosphere. The total $\mathrm{Hg}$ released is promoted by the volatile matter release to some extent while the $\mathrm{Hg}^{0}$ released is mainly affected by the atmospheres used.
\end{abstract}

Keywords: bituminous coal, dynamic release behavior, elemental $\mathrm{Hg}$, thermal treatment

\section{Introduction}

Mercury $(\mathrm{Hg})$ is a toxic trace element in coal with a high volatility. ${ }^{1}$ Because of the tremendous amount of coal used each year, its utilization has been one of the main sources of anthropogenic discharge of $\mathrm{Hg} .{ }^{2} \mathrm{Hg}$ has the persistence and bioaccumulation character, which can strongly affect the environment as well as the human health. ${ }^{3,4}$ Therefore, more and more attention has been paid to the $\mathrm{Hg}$ emission control from coal-fired power plants. ${ }^{5-9}$ Also, a series of strict policies for controlling $\mathrm{Hg}$ emissions have been established, including the emission standard of air pollutants for coal-fired power plant in China. To satisfy the emission standard of $\mathrm{Hg}$, effective $\mathrm{Hg}$ control technology should be introduced to reduce the $\mathrm{Hg}$ emission. Consequently, it is important to develop effective $\mathrm{Hg}$ control technologies.

Generally, $\mathrm{Hg}$ released presents mainly in two forms $\left(\mathrm{Hg}^{2+}\right.$ and $\left.\mathrm{Hg}^{0}\right)$ during coal combustion. The two forms of $\mathrm{Hg}$ show different characteristics and have different migration abilities in environment. The $\mathrm{Hg}^{2+}$ is a local pollutant, which is water-soluble and can fall from the atmosphere quickly. ${ }^{10,11}$ However, the $\mathrm{Hg}^{0}$ is a global pollutant, which is low water solubility with high vapor pressure and can present 3 to 24 months of residence

*e-mail: guosq@tyust.edu.cn time in environment atmosphere with a wide dispersion range. ${ }^{12-14}$ Therefore, the emission control of $\mathrm{Hg}^{0}$ is harder than that of $\mathrm{Hg}^{2+}$ and it becomes the main concern for $\mathrm{Hg}$ pollution control.

To develop an effective $\mathrm{Hg}$ controlling technology, it is necessary to understand the release behavior of $\mathrm{Hg}$ during coal thermal treatment because it happens in most coal conversion processes. In recent years, extensive studies have been focused on the $\mathrm{Hg}$ release during coal combustion and pyrolysis. ${ }^{14-24}$ However, the information about the effect of atmosphere on $\mathrm{Hg}^{0}$ release during thermal treatment of bituminous coal is still limited. In the present paper, the effect of atmosphere on $\mathrm{Hg}^{0}$ release from two bituminous coals during thermal treatment has been studied.

\section{Experimental}

\section{Coal samples}

Two Chinese bituminous coals were used, which were labeled as 1 and 2. The coals were crushed and sieved to $0.16-0.27 \mathrm{~mm}$ and dried before use. Proximate and ultimate analyses of the two coals and the concentration of $\mathrm{Hg}$ contents in the coals are shown in Table 1 . The major mineral elements of the two coals detected by X-ray fluorescence analysis are shown in Table 2. 
Table 1. Proximate and ultimate analyses of the coals

\begin{tabular}{|c|c|c|c|c|c|c|c|c|c|}
\hline \multirow{2}{*}{ Coal sample } & \multirow{2}{*}{$\begin{array}{c}\mathrm{Hg} \text { in coal/ } \\
\left(\mathrm{ng} \mathrm{g}^{-1}\right)\end{array}$} & \multicolumn{3}{|c|}{ Proximate analysis / (wt.\%) } & \multicolumn{5}{|c|}{ Ultimate analysis (daf) / (wt.\%) } \\
\hline & & $\mathrm{V}_{\text {daf }}$ & $\mathrm{A}_{\mathrm{as}}$ & $\mathrm{M}_{\mathrm{as}}$ & $\mathrm{C}$ & $\mathrm{H}$ & $\mathrm{N}$ & $\mathrm{S}$ & $\mathrm{O}^{\mathrm{a}}$ \\
\hline 1 & 132 & 41.69 & 20.29 & 1.81 & 80.16 & 4.34 & 0.85 & 2.37 & 12.28 \\
\hline 2 & 169 & 44.82 & 12.15 & 0.87 & 81.32 & 5.22 & 1.20 & 3.97 & 8.29 \\
\hline
\end{tabular}

${ }^{\mathrm{a} B y}$ difference; V: volatile; A: ash; M: moisture; as: as received; daf: dry and ash free.

Table 2. Major mineral elements in the coals ${ }^{\mathrm{a}}$

\begin{tabular}{cccccccccccccc}
\hline \multirow{2}{*}{ Coal sample } & \multicolumn{10}{c}{ Ash analysis / $\left(\mathrm{g} 100 \mathrm{~g}^{-1}\right)$} \\
\cline { 2 - 20 } & $\mathrm{SiO}_{2}$ & $\mathrm{Al}_{2} \mathrm{O}_{3}$ & $\mathrm{Fe}_{2} \mathrm{O}_{3}$ & $\mathrm{CaO}$ & $\mathrm{MgO}$ & $\mathrm{TiO}_{2}$ & $\mathrm{SO}_{3}$ & $\mathrm{~K}_{2} \mathrm{O}$ & $\mathrm{Na}_{2} \mathrm{O}$ & $\mathrm{P}_{2} \mathrm{O}_{5}$ \\
\hline 1 & 9.42 & 3.91 & 2.83 & 1.20 & 0.84 & 0.27 & 1.04 & 0.41 & 0.28 & 0.09 \\
2 & 3.97 & 1.75 & 2.77 & 1.83 & 0.18 & 0.08 & 1.36 & 0.06 & 0.11 & 0.04 \\
\hline
\end{tabular}

aDry basis.

\section{Thermal treatment experiments}

The thermal treatment process was carried out under $\mathrm{N}_{2}$, $\mathrm{CO}_{2}$ and air atmosphere with a flow rate of $300 \mathrm{~cm}^{3} \mathrm{~min}^{-1}$ in a fixed bed quartz tube reactor from room temperature to $1200^{\circ} \mathrm{C}$ at a heating rate of $20^{\circ} \mathrm{C} \mathrm{min}{ }^{-1} .1 \mathrm{~g}$ (the precision is $0.0002 \mathrm{~g}$ ) of coal sample was charged into a quartz boat. Then, the quartz boat with the coal sample was pushed into the constant temperature zone of the reactor. A thermocouple was placed in the center of the coal sample to measure the temperature. Before thermal treatment of coal, 10 min purge time for the reactor was used to assure the atmosphere $\left(\mathrm{N}_{2}, \mathrm{CO}_{2}\right.$ or air) purity. The release of $\mathrm{Hg}^{0}$ from the thermal treatment of the coals was analyzed dynamically by coupling a temperature-programmed decomposition (TPD) unit with an on-line atomic fluorescence spectrometer (AFS) detector. The volatile products from the thermal treatment of the coals were swept into the AFS detector by purging gas continuously and the $\mathrm{Hg}^{0}$ intensity is recorded by a computer. In this way, a dynamic $\mathrm{Hg}^{0}$ release profile during coal thermal treatment can be obtained. ${ }^{25}$ The detection limit of $\mathrm{Hg}$ in this system is $100 \mathrm{ng} \mathrm{N} \mathrm{m}^{-3}$. The on-line mass spectrometry (MS) (Balzers QMS422) was used to monitor the volatile matter release during the thermal treatment of the coals. At the temperature of $1200^{\circ} \mathrm{C}$, the boat with sample was moved quickly to the cold end of the reactor and cooled down under $\mathrm{N}_{2}$ flow. The weights of the sample were weighed and recorded. $\mathrm{The} \mathrm{Hg}$ contents in chars were analyzed.

Release ratio of elemental mercury is used to quantify the amount of $\mathrm{Hg}^{0}$ released from coal, which is abbreviated as RRE and defined as:

$\operatorname{RRE}(\%)=\frac{\text { elemental } \mathrm{Hg} \text { released }}{\text { total } \mathrm{Hg} \text { in coal }} \times 100(\%)$
Release ratio of total $\mathrm{Hg}$ (RRT) is used to quantify the amount of total mercury released from coal, defined as:

$\operatorname{RRT}(\%)=\frac{\left(\begin{array}{c}\text { Hg concentration } \\ \text { in coal }\end{array}\right)-\left(\begin{array}{c}\text { Hg concentration } \\ \text { in char }\end{array}\right) \times \text { char yield }}{\text { Hg concentration in coal }} \times 100(\%)$

Volatile yield (VY) is used to evaluate the quantity of volatile matters released during the coal thermal treatment, defined as:

VY $(\%)=100-\frac{\text { char mass }}{\text { coal massl }} \times 100(\%)$

\section{Determination of mercury}

The contents of $\mathrm{Hg}$ in the two coals and the chars were determined following the Chinese national standard (GB/T 16659-2008). Firstly, mercury in the coal sample was dissolved in $\mathrm{HNO}_{3}-\mathrm{H}_{2} \mathrm{SO}_{4}$ solution and converted into $\mathrm{Hg}^{2+}$ in the presence of $\mathrm{V}_{2} \mathrm{O}_{5}$. Then, the $\mathrm{Hg}^{2+}$ is reduced to $\mathrm{Hg}^{0}$ with the solution of $\mathrm{KBH}_{4}$. Finally, $\mathrm{Hg}^{0}$ was detected by the atomic fluorescence spectrometer with the detection limit of $0.05 \mathrm{ng} \mathrm{L}^{-1}$. The $\mathrm{Hg}^{0}$ release profiles during the thermal treatment of the coals were obtained by the on-line AFS.

\section{Results and Discussion}

Dynamic release behavior of $\mathrm{Hg}^{0}$ during thermal treatment of two coals under $\mathrm{N}_{2}$

The dynamic $\mathrm{Hg}^{0}$ release profiles versus the increase of temperature for these two coals were measured using TPD-AFS technique and the results are shown in Figure 1, 
which the intensity of all the profiles is normalized for easy comparison.

Figure 1 shows that the initial $\mathrm{Hg}^{0}$ release from the two coals is around $150{ }^{\circ} \mathrm{C}$ and most of the $\mathrm{Hg}^{0}$ releases at temperatures below $600{ }^{\circ} \mathrm{C}$. It indicates that pyrolysis is an effective method to remove $\mathrm{Hg}$ from coals, which somewhat agrees with the $\mathrm{Hg}$ release behavior reported in the literature. ${ }^{18-21}$ Generally, the profiles of $\mathrm{Hg}$ released present two or three well-resolved peaks and most of them are broad and overlapped, indicating the diversity of modes of occurrence of $\mathrm{Hg}$ in the coals. ${ }^{25-29}$ Note that the profiles present the $\mathrm{Hg}$ peaks at similar temperature range for these two coals. For example, two typical peaks can be observed for the two coals. One peak was located in the range of 150 to $400^{\circ} \mathrm{C}$ and the other peak was located in the range of 500 to $600^{\circ} \mathrm{C}$. It indicates the similar modes of occurrence of $\mathrm{Hg}$ in the coals, which possibly are organicbound and pyrite-bound $\mathrm{Hg}$ in coal. ${ }^{30}$ However, the minor peak at $800-900^{\circ} \mathrm{C}$ is only shown for coal 1 , while it is not shown for 2 . This result indicates the existence of different modes of occurrence of $\mathrm{Hg}$ in the coals.

Generally, the $\mathrm{N}_{2}$ is an inert gas and cannot react with coal or other gas. Therefore, the $\mathrm{Hg}$ released profiles under $\mathrm{N}_{2}$ shown in Figure 1 can be regarded as the thermal stability of the mercury in the coals. Actually, the most known $\mathrm{Hg}$ compounds are thermally unstable above $700{ }^{\circ} \mathrm{C} .{ }^{31-33}$ However, Figure 1 shows the $\mathrm{Hg}$ released peak at $800-900{ }^{\circ} \mathrm{C}$ for coal 1 . According to Guo et al. ${ }^{30}$ the $\mathrm{Hg}$ released above $700^{\circ} \mathrm{C}$ should be silicate-bound $\mathrm{Hg}$ in coal. In addition, the major mineral elements in the coals listed in Table 2 shows that 1 has higher content of $\mathrm{SiO}_{2}$ and $\mathrm{Al}_{2} \mathrm{O}_{3}$ than coal 2. Therefore, the $\mathrm{Hg}$ peak at $800-900^{\circ} \mathrm{C}$ for coal 1 is probably due to the influence of silicates or aluminosilicates. $^{34}$

The amount of $\mathrm{Hg}$ released after TPD process for the two coals is listed in Table 3, in which the amount of $\mathrm{Hg}$ released as $\mathrm{Hg}^{0}$ (RRE) was calculated based on AFS profile ${ }^{25}$ and the amount of total $\mathrm{Hg}$ released (RRT) was calculated by comparing the mercury content in raw coal and char at $1200{ }^{\circ} \mathrm{C}$. The result shows that higher than $92 \%$ of total $\mathrm{Hg}$ in the coals releases in $\mathrm{Hg}^{0}$ form
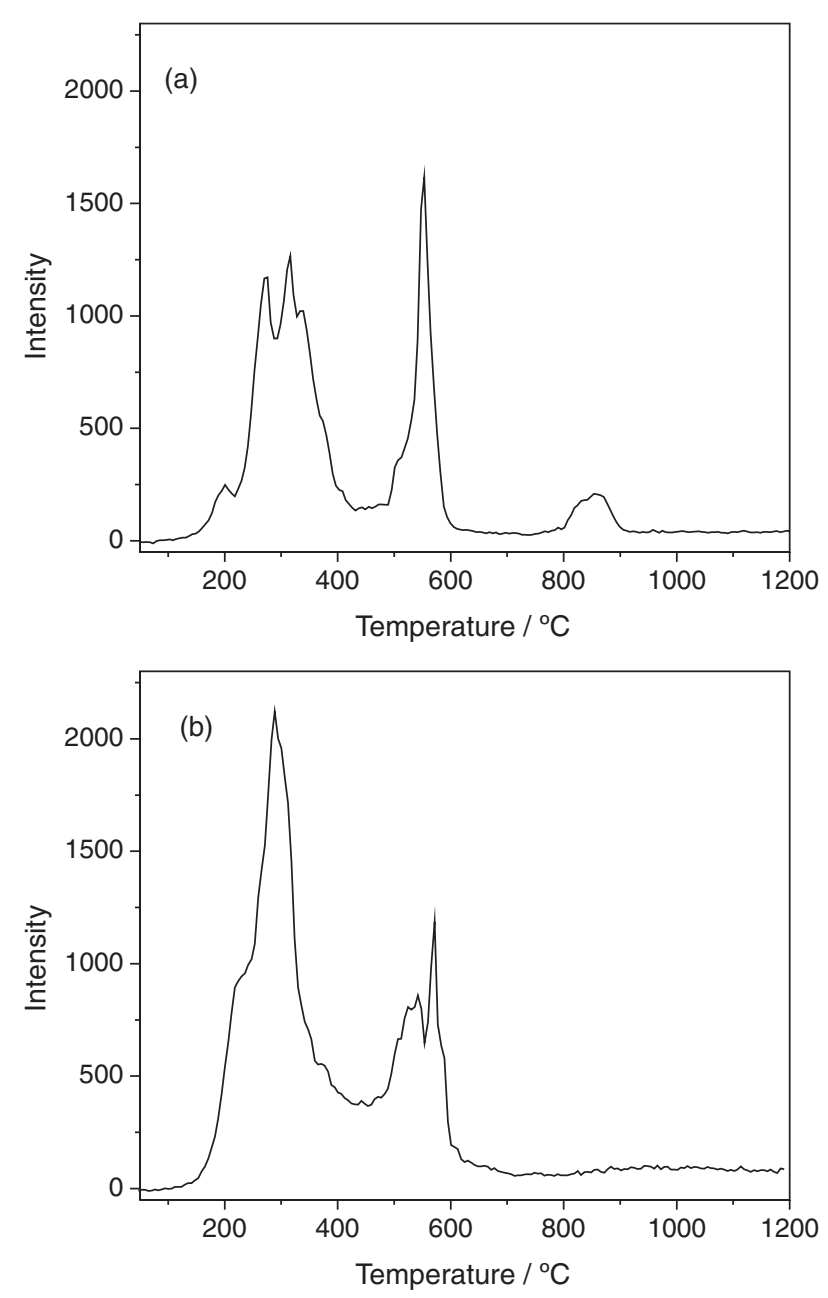

Figure 1. Dynamic release behavior of $\mathrm{Hg}^{0}$ during thermal treatment of two coals under $\mathrm{N}_{2}$, (a) 1 ; (b) 2 .

under $\mathrm{N}_{2}$. Meanwhile, approximately $94-95 \%$ of total $\mathrm{Hg}$ in the coals releases out during thermal treatment under $\mathrm{N}_{2}$. Because the RRE is nearly equal to the RRT for the two coals used, it may be concluded that the $\mathrm{Hg}^{\mathrm{O}}$ is dominant form of $\mathrm{Hg}$ released from the coals during thermal treatment under $\mathrm{N}_{2 .}{ }^{35}$

The previous study reported that the modes of occurrence of $\mathrm{Hg}$ in the coals can be characterized based on the profiles in Figure 1 and the detailed discussions were given in the literature..$^{30}$ The $\mathrm{Hg}$ in coal can be separated

Table 3. The amount of Hg released and VY during thermal treatment of two coals

\begin{tabular}{|c|c|c|c|c|c|c|c|c|c|}
\hline \multirow{2}{*}{$\frac{\text { Coal }}{\text { Sample }}$} & \multicolumn{3}{|c|}{ Under $\mathrm{N}_{2} / \%$} & \multicolumn{3}{|c|}{ Under $\mathrm{CO}_{2} / \%$} & \multicolumn{3}{|c|}{ Under air / \% } \\
\hline & $\mathrm{RRE}^{\mathrm{a}}$ & $\mathrm{RRT}^{\mathrm{b}}$ & $\mathrm{VY}^{\mathrm{c}}$ & $\mathrm{RRE}^{\mathrm{a}}$ & $\mathrm{RRT}^{\mathrm{b}}$ & $\mathrm{VY}^{\mathrm{c}}$ & $\mathrm{RRE}^{\mathrm{a}}$ & $\mathrm{RRT}^{\mathrm{b}}$ & $V Y^{c}$ \\
\hline 1 & 92.1 & 94.3 & 30.84 & 73.6 & 97.3 & 77.97 & 31.1 & 98.5 & 80.70 \\
\hline 2 & 93.5 & 94.2 & 36.85 & 73.4 & 96.5 & 81.94 & 32.6 & 99.4 & 88.94 \\
\hline
\end{tabular}

${ }^{a}$ Based on the AFS profile; baccording to the mercury content in raw coal and char; 'according to the mass of raw coal and char; RRE: release ratio of elemental mercury; RRT: amount of total Hg released; VY: volatile yield. 
into four modes of occurrence of $\mathrm{Hg}$ : the organic-bound $\mathrm{Hg}$, the silicate-bound $\mathrm{Hg}$, the pyrite-bound $\mathrm{Hg}$ and the $\mathrm{HCl}$-soluble $\mathrm{Hg} .{ }^{30}$ For coal 1, it contains all the four modes of occurrence of $\mathrm{Hg}$ whereas coal 2 contains three modes of occurrence of $\mathrm{Hg}$ without the silicate-bound released in the temperature range $>750{ }^{\circ} \mathrm{C} .{ }^{30}$

Dynamic release behavior of $\mathrm{Hg}^{0}$ during thermal treatment of two coals under $\mathrm{CO}_{2}$

The dynamic $\mathrm{Hg}^{0}$ release profiles versus the increase of temperature for two coals under $\mathrm{CO}_{2}$ atmosphere are shown in Figure 2. Also, the intensity of the profiles is normalized.
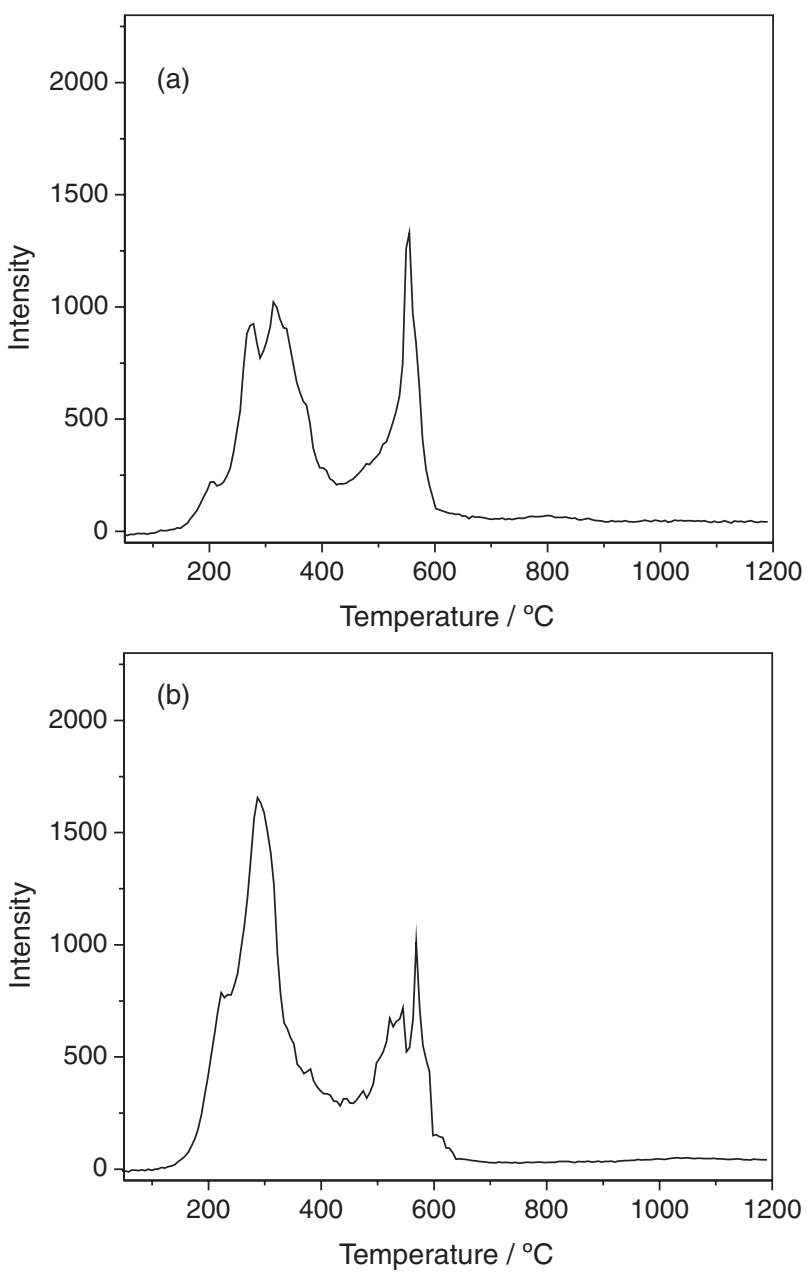

Figure 2. Dynamic release behavior of $\mathrm{Hg}^{0}$ during thermal treatment of two coals under $\mathrm{CO}_{2}$, (a) 1 ; (b) 2 .

Similar to the release behavior of $\mathrm{Hg}^{0}$ under $\mathrm{N}_{2}$, the profiles also show several peaks and the $\mathrm{Hg}^{0}$ starts to release at about $150^{\circ} \mathrm{C}$. Note that the shape of the peaks $<600^{\circ} \mathrm{C}$ under $\mathrm{CO}_{2}$ is similar to that under $\mathrm{N}_{2}$ except that the intensity of the corresponding peaks under $\mathrm{CO}_{2}$ is slightly lower than that under $\mathrm{N}_{2}$. However, the peaks at $800-900^{\circ} \mathrm{C}$ under $\mathrm{N}_{2}$ for coal 1 almost disappear after the thermal treatment under $\mathrm{CO}_{2}$.

The RRE and RRT under $\mathrm{CO}_{2}$ are listed in Table 3. It shows that the amount of $\mathrm{Hg}^{0}$ released under $\mathrm{CO}_{2}$ counts for $73-74 \%$ of $\mathrm{Hg}$ in the coals, which is lower than that under $\mathrm{N}_{2}$. However, the amount of total $\mathrm{Hg}$ released counts for 96-98\% of $\mathrm{Hg}$ in the coals and higher than that under $\mathrm{N}_{2}$ at temperature range studied. It indicates that $\mathrm{CO}_{2}$ atmosphere restrains the $\mathrm{Hg}^{0}$ release and promotes the total $\mathrm{Hg}$ release to some extent. ${ }^{36}$

In fact, the thermal treatment of the coals under $\mathrm{CO}_{2}<800{ }^{\circ} \mathrm{C}$ is the process of pyrolysis due to the gasification of the coals that cannot occur at lower temperature range. Therefore, the behavior of $\mathrm{Hg}^{0}$ release is similar to that under $\mathrm{N}_{2}$ at lower temperature range. Generally, $\mathrm{CO}_{2}$ can be produced as part of volatile matter during coal pyrolysis. ${ }^{37,38}$ Also, the result of MS verifies the production of $\mathrm{CO}_{2}$ during pyrolysis of the coals. The $\mathrm{CO}_{2}$ release behavior during thermal treatment of two coals under $\mathrm{N}_{2}$ is shown in Figure 3. Theoretically, coal pyrolysis is a complex chemical reaction and $\mathrm{CO}_{2}$ gas is part of the reaction product. ${ }^{37}$ When the additional $\mathrm{CO}_{2}$ is introduced into the reaction system, it inhibits the reaction to a certain degree according to the theory of chemical reaction balance, leading to the decrease of the volatile matter produced during coal pyrolysis. Consequently, $\mathrm{Hg}^{0}$ as part of volatile matter or reaction product during coal pyrolysis is also inhibited, resulting in a lower $\mathrm{Hg}$ peaks than that under $\mathrm{N}_{2}$.

The thermal treatment of coal under $\mathrm{CO}_{2}>800{ }^{\circ} \mathrm{C}$ is a process of coal gasification because coal can react with $\mathrm{CO}_{2}$ at high temperature. ${ }^{39,40}$ And the coal gasification promotes the volatile matter release, leading to a dramatic increase of VY for both coals (see Table 3). It seems that the $\mathrm{Hg}^{0}$ release should be promoted by the coal gasification because the coal matrix is destroyed and the $\mathrm{Hg}$ in it can easy release out during the coal gasification. However, contrary to what we suspect, the $\mathrm{Hg}^{0}$ release even decreases. It might be caused by $\mathrm{CO}_{2}$. For example, $\mathrm{CO}_{2}$ can react with $\mathrm{C}\left(\mathrm{C}+\mathrm{CO}_{2}=2 \mathrm{CO}\right)$ during coal gasification. ${ }^{40}$ Similarly, $\mathrm{CO}_{2}$ could react with $\mathrm{Hg}^{0}$ during coal gasification, resulting in a decrease of $\mathrm{Hg}^{0}$ release. ${ }^{41}$

It should be pointed out that the VY for the two coals at temperature $<800{ }^{\circ} \mathrm{C}$ under $\mathrm{CO}_{2}$ is less than that under $\mathrm{N}_{2}$ whereas the VY at temperature $>800{ }^{\circ} \mathrm{C}$ under $\mathrm{CO}_{2}$ is higher than that under $\mathrm{N}_{2}$. For example, the VY for coal 1 at 700 and $1200^{\circ} \mathrm{C}$ under $\mathrm{N}_{2}$ is 25.38 and $30.84 \%$, respectively, while that under $\mathrm{CO}_{2}$ is 24.27 and $77.97 \%$, respectively. This implies that the $\mathrm{CO}_{2}$ atmosphere restrains the volatile matter release $<800{ }^{\circ} \mathrm{C}$ and promotes the volatile matter release $>800{ }^{\circ} \mathrm{C}$. 

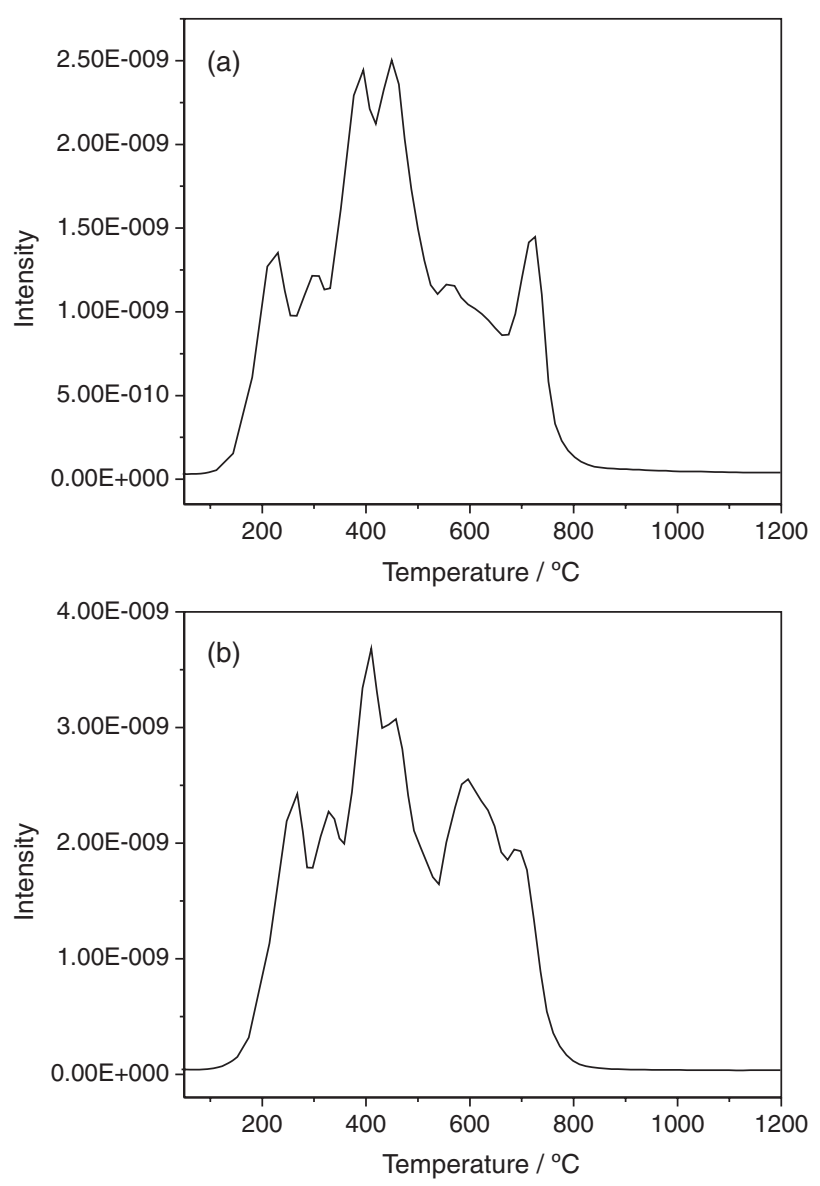

Figure 3. Release behavior of $\mathrm{CO}_{2}$ during thermal treatment of two coals under $\mathrm{N}_{2}$, (a) 1; (b) 2 .

Dynamic release behavior of $\mathrm{Hg}^{0}$ during thermal treatment of two coals under air

The dynamic $\mathrm{Hg}^{0}$ release profiles versus the increase of temperature for two coals under air are shown in Figure 4. The intensity of the profiles is also normalized.

Figure 4 shows that the profile of the peaks is different with that under $\mathrm{N}_{2}$ and $\mathrm{CO}_{2}$ atmosphere. In addition, the peak intensity under air is distinctly lower than that under $\mathrm{N}_{2}$ and $\mathrm{CO}_{2}$ atmosphere, which indicates a lower $\mathrm{Hg}^{0}$ release under air. Note that the peaks in Figure 4 show similar profiles at $200-500{ }^{\circ} \mathrm{C}$ for both coals, possibly attributing to the similar modes of occurrence of $\mathrm{Hg}$ in the coals. However, the peaks at temperature $>500{ }^{\circ} \mathrm{C}$ under $\mathrm{N}_{2}$ and $\mathrm{CO}_{2}$ for these two coals almost disappear after the thermal treatment under air. This result implies that the $\mathrm{Hg}$ released at temperature $>500{ }^{\circ} \mathrm{C}$ under air is mainly oxidized $\mathrm{Hg}$.

The RRE and RRT under air (in Table 3) show that the amount of $\mathrm{Hg}^{0}$ released under air counts for $31-33 \%$ of $\mathrm{Hg}$ in coal and is distinctly less than that under $\mathrm{N}_{2}$ and $\mathrm{CO}_{2}$. However, the amount of total $\mathrm{Hg}$ released is higher than that under $\mathrm{N}_{2}$ and $\mathrm{CO}_{2}$. This result indicates that a large part
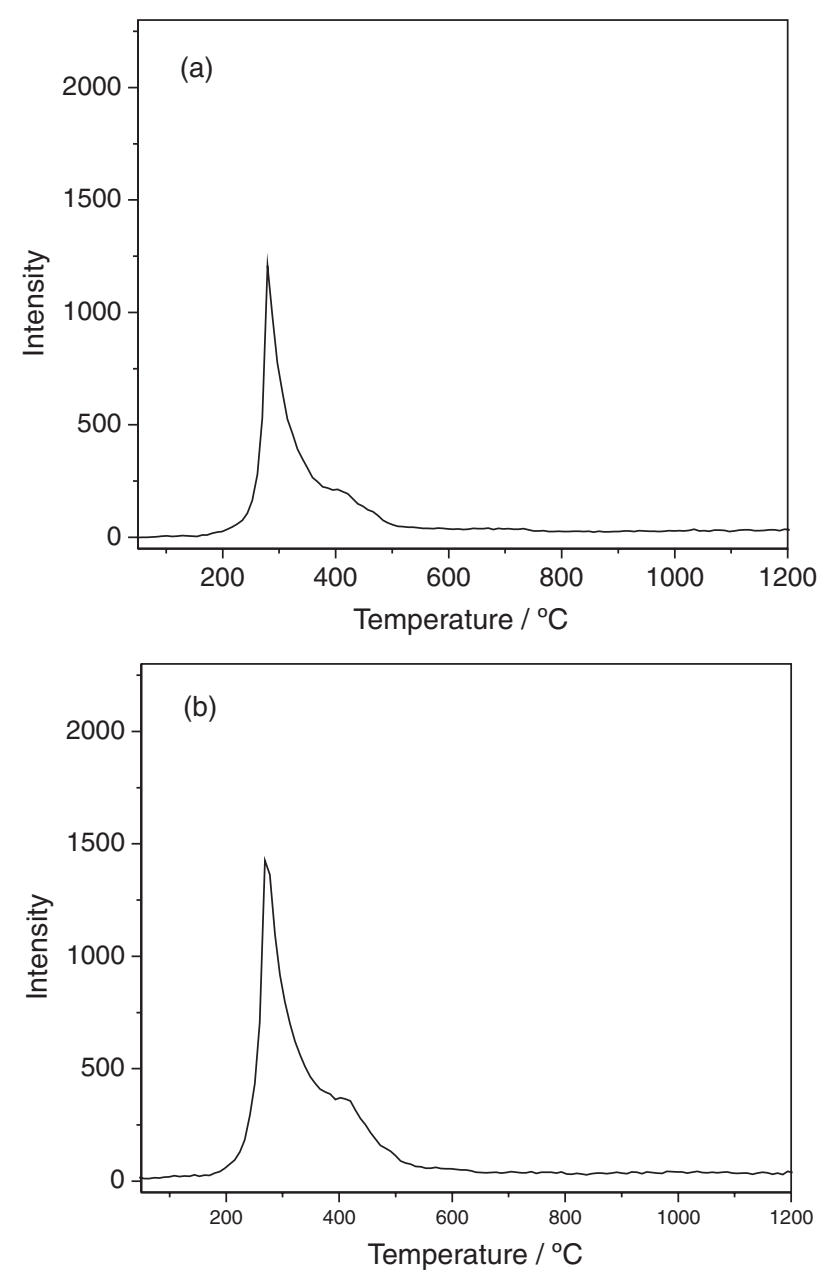

Figure 4. Dynamic release behavior of $\mathrm{Hg}^{0}$ during thermal treatment of two coals under air, (a) 1 ; (b) 2 .

of $\mathrm{Hg}^{0}$ has been converted into oxidation state of $\mathrm{Hg}$ by the oxygen in the air. ${ }^{42}$ Table 3 shows that the VY under air is higher than that under $\mathrm{N}_{2}$ and $\mathrm{CO}_{2}$. However, the higher VY under air does not promote the $\mathrm{Hg}^{0}$ release because of the formation of the oxidized $\mathrm{Hg}$ during thermal treatment of the two coals under air. ${ }^{42}$

\section{Conclusions}

A study was made to understand the release behavior of $\mathrm{Hg}^{0}$ from two bituminous coals under different atmospheres during thermal treatment. The profiles of $\mathrm{Hg}^{0}$ released present several peaks during thermal treatment of these two coals. With the different atmosphere used, the profiles are also different for the same coal, which indicates that the release behavior of $\mathrm{Hg}^{0}$ is affected by the atmosphere used. Generally, the RRE is in the order of $\mathrm{N}_{2}>\mathrm{CO}_{2}>$ air. The RRE for both coals is higher than $92 \%$ under $\mathrm{N}_{2}$, which is nearly equal to the RRT under $\mathrm{N}_{2}$ atmosphere. This result indicates that the $\mathrm{Hg}^{0}$ released is the dominant 
form during thermal treatment of these two coals under $\mathrm{N}_{2}$. The RRE is approximately $73-74$ and $31-33 \%$ under $\mathrm{CO}_{2}$ and air atmosphere, respectively, which is less than the corresponding RRT. This indicates that a part of $\mathrm{Hg}^{0}$ has been converted into the oxidized $\mathrm{Hg}$ during thermal treatment of these two coals under $\mathrm{CO}_{2}$ and air atmosphere.

\section{Acknowledgments}

The authors gratefully acknowledge the financial support from the Natural Science Foundation of China (41372350).

\section{References}

1. Lukasz, U.; Jerzy, G.; Mariusz, M.; Fuel Process. Technol. 2015, 140, 12 .

2. Jesse, L. A.; Lynne, E. G.; Daniel, A. J.; Environ. Sci. Technol. 2015, 49, 10389.

3. Fok, T. F.; Lam, H. S.; Ng, P. C.; Yip, A. S.; Sin, N. C.; Chan, I. H.; Gu, G. J.; So, H. K.; Wong, E. M.; Lam, C. W.; Environ. Int. 2007, 33, 84.

4. Ribeiro, A. S.; Vieira, M. A.; Curtius, A. J.; J. Braz. Chem. Soc. 2004, 15, 825.

5. Liu, K.; Gao, Y.; Riley, J. T.; Pan, W. P.; Mehta, A. K.; Ho, K. K.; Smith, S. R.; Energy Fuels 2001, 15, 1173.

6. Camera, A. S.; Maranhão, T. A.; Oliveira, F. J. S.; Silva, J. S. A.; Frescura, V. L. A.; J. Braz. Chem. Soc. 2015, 26, 2116.

7. Tan, Y.; Mortazavi, R.; Dureau, B.; Douglas, M. A.; Fuel 2004, 83, 2229.

8. Laudal, D. L.; Brown, T. D.; Nott, B. R.; Fuel Process. Technol. 2000, 65-66, 157.

9. de Gois, J. S.; Borges, D. L. G.; J. Braz. Chem. Soc. 2014, 25 , 1601.

10. Ren, J.; Zhou, J.; Luo, Z.; Cen, K.; Acta Sci. Circumstantiae 2002, 22, 289.

11. Wang, J.; Clements, B.; Zanganeh, K.; Fuel 2003, 82, 1009.

12. Zheng, C.; Liu, J.; Liu, Z.; Xu, M.; Liu, Y.; Fuel 2005, 84, 1215.

13. Yudovich, Y. E.; Ketris, M. P.; Int. J. Coal Geol. 2005, 62, 135.

14. Li, H.; Li, Y.; Wu, C.; Zhang, J.; Chem. Eng. J. 2011, 169, 186.

15. Wilcox, J.; Rupp, E.; Ying, S. C.; Lim, D. H.; Negreira, A. S.; Kirchofer, A.; Feng, F.; Lee, K.; Int. J. Coal Geol. 2012, 90, 4.

16. Pavlish, J. H.; Holmes, M. J.; Benson, S. A.; Crocker, C. R.; Galbreath, K. C.; Fuel Process. Technol. 2004, 85, 563.

17. Senior, C. L.; Sarofim, A. F.; Zeng, T.; Helble, J. J.; MamaniPaco, R.; Fuel Process. Technol. 2000, 63, 197.
18. Guffey, F. D.; Bland, A. E.; Fuel Process. Technol. 2004, 85, 521.

19. Wang, M.; Keener, T. C.; Khang, S.; Fuel Process. Technol. 2000, 67, 147.

20. Iwashita, A.; Tanamachi, S.; Nakajima, T.; Takanashi, H.; Ohki, A.; Fuel 2004, 83, 631.

21. Merdes, A. C.; Keener, T. C.; Khang, S.; Jenkins, R. G.; Fuel 1998, 77, 1783.

22. Wu, H.; Li, C.; Zhao, L.; Energy Fuels 2015, 29, 6747.

23. Zhao, L.; Li, C.; Zhang, J.; Fuel 2015, 153, 361.

24. Wang, J.; Zhang, Y.; Han, L.; Chang, L.; Bao, W.; Fuel 2013, 103,73 .

25. Guo, S.; Yang, J.; Liu, Z.; Energy Fuels 2009, 23, 4817.

26. Zheng, L.; Liu, G.; Chou, C.; Int. J. Coal Geol. 2008, 73, 19.

27. Zheng, L.; Liu, G.; Qi, C.; Zhang, Y.; Wong, M.; Int. J. Coal Geol. 2008, 73, 139.

28. Luo, G.; Yao, H.; Xu, M.; Gupta, R.; Xu, Z.; Proc. Combust. Inst. 2011, 33, 2763.

29. Diehl, S. F.; Goldhaber, M. B.; Hatch, J. R.; Int. J. Coal Geol. 2004, 59, 193.

30. Guo, S.; Yang, J.; Liu, Z.; Energy Fuels 2012, 26, 3388.

31. Wu, S.; Uddin, M. A.; Nagano, S.; Ozaki, M.; Sasaoka, E.; Energy Fuels 2011, 25, 144.

32. Lopez-Anton, M. A.; Yuan, Y.; Perry, R.; Maroto-Valer, M. M.; Fuel 2010, 89, 629.

33. Biester, H.; Scholz, C.; Environ. Sci. Technol. 1997, 31, 233.

34. Liu, R.; Yang, J.; Xiao, Y.; Liu, Z.; Energy Fuels 2009, 23, 2013.

35. Liu, L.; Duan, Y.; Wang, Y.; Wang, H.; Yin, J.; J. Fuel Chem. Technol. 2010, 38, 134.

36. Yang, L.; Zhang, J.; He, B.; Zhao, Y.; Yu, C.; Wang, Z.; Zheng, C.; J. Eng. Thermophys. 2008, 29, 1775.

37. Zhong, M.; Zhang, Z.; Zhou, Q.; Yue, J.; Gao, S.; Xu, G.; J. Anal. Appl. Pyrolysis 2012, 97, 123.

38. Scaccia, S.; Calabrò, A.; Mecozzi, R.; J. Anal. Appl. Pyrolysis 2012, 98, 45.

39. Micco, G. D.; Nasjleti, A.; Bohé, A. E.; Fuel 2012, 95, 537.

40. Li, Z.; Zhang, X.; Sugai, Y.; Wang, J.; Sasaki, K.; Energy Procedia 2011, 4, 1252.

41. Guo, S.; Yang, J.; Liu, Z.; J. Fuel Chem. Technol. 2008, $36,397$.

42. Galbreath, K. C.; Zygarlicke, C. J.; Olson, E. S.; Sci. Total Environ. 2000, 261, 149. 